\title{
Níveis de compreensão de leitura em escolares****
}

\author{
Reading comprehension levels in scholars
}

\author{
Carolina Alves Ferreira de Carvalho* \\ Clara Regina Brandão de Ávila** \\ Brasília Maria Chiari***
}

\begin{abstract}
*Fonoaudióloga. Mestre em Distúrbios da Comunicação Humana pela Universidade Federal de São Paulo. Endereço para correspondência: Rua Napoleão de Barros, 874 - São Paulo - SP - CEP 04024-001 (carolcarvalho_fono@yahoo.com.br).

**Fonoaudióloga. Doutora em Distúrbios da Comunicação Humana pela Universidade Federal de São Paulo. Professora Associada do Curso de Fonoaudiologia da Universidade Federal de São Paulo.

***Fonoaudióloga. Doutora em Distúrbios da Comunicação Humana pela Universidade Federal de São Paulo. Professora Titular do Curso de Fonoaudiologia da Universidade Federal de São Paulo.

****Trabalho Realizado na Universidade Federal de São Paulo Apoio Fundação de Amparo à Pesquisa do Estado de São Paulo - Fapesp.
\end{abstract}

Artigo Original de Pesquisa

Artigo Submetido a Avaliação por Pares

Conflito de Interesse: não

Recebido em 07.08.2008.

Revisado em 22.10.2008; 12.02.2009.

Aceito para Publicação em 16.07.2009.

\begin{abstract}
Background: important reading performance measurements are related to how and to what extent a child understands a written text. Aim: to study the performance of primary school (Ensino Fundamental) students in reading comprehension tasks according to the variables grade and type of school. Method: 160 students from the 3rd to the 6th grades were screened and later evaluated based on the retelling and question answering about a given text. Results: students of the 5th and 6th grades of private schools presented a better performance on issues related to implicit information when compared to students of public schools. The overall analysis of the educational level revealed, through the retelling task, a better performance of the 6th grade students in terms of the number of present macro propositions and a low performance of the 5th grade students in terms of the achieved comprehension level, in both types of school. When answering text-derived questions, the 4th, 5th and 6th grade students performed better than the 3rd grade students regarding explicit questions. When considering implicit questions, the 4th grade students performed better than all the other grades, in both types of school. These results gave evidence to the influence of the different texts used in each grade. Conclusion: the 5th and 6th grades from private schools were the only grades that performed better when compared to public schools in general, regarding answering implicit knowledge questions. All students achieved some level of reading comprehension.
\end{abstract}

Key Words: Evaluation; Reading; Comprehension.

\section{Resumo}

Tema: importantes medidas de desempenho de leitura estão relacionadas com o quanto e como a criança compreende um texto. Objetivo: estudar o desempenho de escolares do Ensino Fundamental em tarefas de compreensão de leitura, segundo as variáveis série e rede de ensino. Método: 160 escolares de $3^{\mathrm{a}}$ a $6^{\mathrm{a}}$ séries do Ensino Fundamental, foram triados e posteriormente avaliados por meio do reconto e respostas a questões sobre o texto. Resultados: os escolares da rede particular apresentaram melhor desempenho nas questões relacionadas a informações implícitas do texto nas $5^{\mathrm{a}} \mathrm{s}$ e $6^{\mathrm{a}} \mathrm{s}$ séries quando comparados aos da rede pública. A análise geral do efeito da escolaridade mostrou, na tarefa de reconto, desempenho melhor das $6^{\mathrm{a}} \mathrm{s}$ séries quanto ao número de macroproposições presentes e desempenho pior das $5^{\mathrm{a}} \mathrm{s}$ séries quanto ao nível de compreensão alcançado, em ambas as redes de ensino. Os escolares de $4^{\mathrm{a}}, 5^{\mathrm{a}}$ e $6^{\mathrm{a}}$ séries apresentaram melhor desempenho que os de $3^{\mathrm{a}}$ nas respostas a questões explícitas. A $4^{\mathrm{a}}$ série apresentou melhor desempenho nas questões implícitas que todas as outras séries, em ambas as redes. Estes resultados evidenciaram a influência dos diferentes textos utilizados em cada série. Conclusão: apenas nas $5^{\mathrm{a}} \mathrm{s}$ e $6^{\mathrm{a}} \mathrm{S}$ séries foi verificado melhor desempenho da rede particular em relação à pública, nas respostas a questões de conhecimento implícito. Todos os escolares mostraram ter alcançado algum nível de compreensão de leitura do texto.

Palavras-Chave: Avaliação; Leitura; Compreensão.

Referenciar este material como:

1 Carvalho CAF, Ávila CRB, Chiari BM. Reading comprehension levels in scholars (original title: Níveis de compreensão de leitura em escolares). Pró-Fono Revista $\sum 3$ de Atualização Científica. 2009 jul-set;21(3):207-12. 


\section{Introduction}

Both decoding and comprehension are studied by researchers who investigate reading and its disorders. Comprehension - which stems such from ownership or development of the written code, as from lexical variety and ability of certain cognitive and metacognitive mechanisms - is capable of promoting knowledge acquisition, self-learning and academic success 1-4. The most important measures of reading performance are related to how much and how the child comprehends a text 3 and allow identifying procedures and processes that underlie comprehension5,6. Comprehension occurs at different levels such from more superficial to levels that allow the creative use of text information and the answering of questions which answers are not literally written, or still, the identification of problems occurring during reading and the search for manners to solve them (self-regulation) 1,7,8. Reading tests performance differences found among children showed that the development of cognitive processes and language interferes with comprehension9.

To date, there is no consensus on the best method to assess reading comprehension because each procedure emphasizes one aspect involved (integration of text information, generation of inferences, monitoring, etc.) 6 .

This research proposed to develop a mean of assessing the reading comprehension level of school age children considered good readers. For such, the performance of students of Junior High School in reading comprehension tasks, according to the variables grade and school type - private or public - was investigated.

\section{Methods}

This study was approved by the Research Ethics Committee of UNIFESP ( $\left.\mathrm{n}^{\circ} 0839 / 06\right)$.

Reading comprehension was assessed by examining the oral retelling of the silently read text, and the answers to multiple choice questions. For such, a Protocol of Reading Comprehension Assessment (PRCA) was developed. Four narrative texts1 were selected from: a study conducted in 20049; textbooks; and the "Tipiti Language Test" 10. Up to six multiple choice questions, with four alternatives each, were elaborated for each text. Three questions concerned explicit propositions and the others assessed the comprehension of implicit text propositions9,11. Five judges, professionals of different areas, mapped the macrostructure of each text, based on the Model of
Textual Comprehension and Production12,13. Each text was then represented by its macropropositions, classified as essential and non-essential, according to the importance and relevance for construction of the global idea and story comprehension. The other propositions were only quantified and not considered for this analysis.

Sample selection

From 185 children listed by their teachers as good readers, 160 (95 girls and 65 boys) who met the following inclusion criteria were selected: parents signature of the consent form; no auditory and visual (not corrected) complaints related to neurological, behavioral or cognitive disorders or to learning disabilities; and lack of school retention. Participants were between eight and 12 years old and were enrolled from 3rd to 6th grade in Public Schools (PuS) or Private Schools (PrS) of the Districts of São Paulo and Santana do Parnaiba. Each grade was represented by 40 students (20 from each school setting - Public and Private). Participants received Language screening (protocol based on the "Bateria de Recepção e Produção da Linguagem Verbal"14) to ensure the absence of language disorders involved in reading comprehension. They were also evaluated on tasks of decoding 15-17 with the aim of removing from the sample students with low values of speed and accuracy, factors that could also interfere on reading comprehension 1, 6, 9, 11 .

\section{Procedures}

After reading a text indicated to their respective grades, participants were immediately subjected to two tests: a) retelling 9,11 b) answering to written multiple choice questions about the same story 2,9,11,18.

The texts were presented printed on A4 paper (Arial 12 font, 1.5 spacing).

Each child was informed that, after reading, he/ she would have to retell the story and answer a few questions about the text. If desired, the child could re-read the text before retelling. The text was removed when the child reported being ready 19.

All retellings were recorded on an mp4 recorder. In a first step of analysis, two retelling profile (RP) that expressed different levels of comprehension were established: Level 1 (absence of one or more than one essential macropropositions); Level 2 (expression pattern with all the essential macropropositions). Each retelling was analyzed once more and, from the RP, ranked according to the comprehension level achieved. 
The answers to multiple choice questions were computed according to the correct alternative.

Parents and teachers of children who failed the screening were counseled about the importance of a complete Speech-Language Pathology assessment.

The results were statistically analyzed by different tests (indicated in tables) with the SPSS program (Statistical Package for Social Sciences) version 13.0. The significance level of 5\% (0.05) was adopted for the application of all statistical tests.

\section{Results}

The initial assessment, which allowed the exclusion of students who showed speed and accuracy values smaller than expected, showed statistical differences with better performance in the 3rd and 4th series of PrS (for speed and accuracy $\mathrm{p}<0001 *)$. This performance was similar on 5th and 6th grades of both settings.

The results concerning the different tasks of comprehension assessment showed, by means of general analysis, that only the number of correct

TABLE 1. Mean and Median Percentage obtained on reading comprehension evaluation according to grade and school setting - Public or Private.

\begin{tabular}{|c|c|c|c|c|c|}
\hline & Grade & & $\operatorname{PrS}$ & $\mathrm{PuS}$ & t Test (p) \\
\hline \multirow{9}{*}{ Macropropositions } & $3 \mathrm{rd}$ & Mean & 0,8 & 0,8 & \multirow{3}{*}{0,602} \\
\hline & \multirow{3}{*}{ 4th } & SD & 0,2 & 0,3 & \\
\hline & & Mean & 0,7 & 0,7 & \\
\hline & & $\mathrm{SD}$ & 0,2 & 0,2 & \multirow[t]{2}{*}{0,700} \\
\hline & \multirow[t]{2}{*}{5 th } & Mean & 0,7 & 0,6 & \\
\hline & & SD & 0,1 & 0,2 & \multirow[t]{2}{*}{0,162} \\
\hline & \multirow[t]{2}{*}{ 6th } & Mean & 0,9 & 0,9 & \\
\hline & & SD & 0,1 & 0,2 & $\begin{array}{c}0,188 \\
\text { Mann-Whitney }\end{array}$ \\
\hline & \multicolumn{2}{|l|}{ Grade } & $\operatorname{PrS}$ & $\mathrm{PuS}$ & $\begin{array}{c}\text { Mann-Whitney } \\
\text { Test } \\
\text { (p) }\end{array}$ \\
\hline \multirow{4}{*}{ Explicit Questions } & $3 \mathrm{rd}$ & Median & 2,0 & 2,0 & 0,341 \\
\hline & 4th & Median & 3,0 & 3,0 & 0,738 \\
\hline & 5th & Median & 3,0 & 3,0 & 0,640 \\
\hline & 6th & Median & 3,0 & 3,0 & 0,429 \\
\hline \multirow{4}{*}{ Implicit Questions } & $3 \mathrm{rd}$ & Median & 2,0 & 2,0 & 0,461 \\
\hline & 4th & Median & 3,0 & 3,0 & 0,289 \\
\hline & 5 th & Median & 2,0 & 1,0 & $0,003 *$ \\
\hline & 6th & Median & 2,5 & 1,5 & $0,033 *$ \\
\hline \multirow{4}{*}{ Level of } & $3 \mathrm{rd}$ & Median & 2,0 & 2,0 & 0,652 \\
\hline & 4th & Median & 2,0 & 2,0 & 0,602 \\
\hline & 5 th & Median & 1,0 & 1,0 & 0,799 \\
\hline & 6th & Median & 2,0 & 1,5 & 0,183 \\
\hline
\end{tabular}

$\mathrm{SD}=$ Standard Deviation answers of information implicit on the text differentiated children from the two school settings - public and private - with better performance of $\operatorname{PrS}(\mathrm{p}=0002 *)$.

When data were analyzed according to the grade (Table 1), similarity of responses in all grades of the two settings were observed - except for 5th and 6th of PrS that presented better performance in questions related to information implicit in the text. These results confirmed those found in the overall analysis and identified the grade at which the difference occurred.

Table 2 shows that on the retelling task, the PuS 6 th grade presented larger number of macropropositions than 4th and 5th did. On PrS, 6th grade performance was better than 3rd, 4th and 5th. In the same task, according to comprehension level, more PuS students of 3rd and 4th grades reached Level 2 than of those of 5th and 6th. In PrS, the performance of the 5 th grade was the poorest one.

Regarding questions about explicit information, in both school settings, students from 4th, 5th and 6th grades performed significantly better than the ones from 3rd grade. However, for questions involving implicit information, the $\mathrm{PuS} 4$ th grade obtained better performance than the others. The 3rd grade also presented better performance than the 5th and 6th did. In PrS, the 4th grade also showed better performance than the others.

\section{Discussion}

In general data analysis, only answers to implicit questions differentiate the PrS children, who presented better performance than the PuS ones. The other tasks showed that all students, considered good readers, behavior in a similar manner when retelling the story or answering questions of explicit knowledge. The comparative analysis evidenced that the comprehension disparity occurred on the 5th and 6th grades. When analyzing the results across grades, it should be emphasized that, with respect to decoding (speed and accuracy), students of PrS showed better performance on initial grades. This difference, however, was not present on 5th and 6th grades, which showed that, in these grades, students of both educational settings presented similar decoding conditions.

However, further differences were found on the comprehension task in more advanced grades, suggesting that reading learning is an ongoing process and that comprehension obtained by generation of inferences could be achieved later. These results have support in the literature. Studies 
also showed that text comprehension is based on different language abilities - from lexical knowledge (low order), such as the efficiency on word recognition and vocabulary knowledge, and knowledge of grammatical structure; to high order text processing as the generation of inferences 2 7,20-22. These abilities develop and achieve different levels according to age, education, reading practice and the stimulation received by the student.

If, on one hand, basic reading skills are related to the recognition of words on the text, on the other one, high-order skills are related to the comprehension of concepts and ideas conveyed. In the learning context, comprehension occurs by identifying the meaning of the text as a whole, not as a series of sentences or individual words. In fact, one of the most consistent findings in the literature about reading is that the construction of coherent representation of text, in memory, is central to the success of comprehension. Coherence reflects the degree of connection between the meanings of text elements and prior reader knowledge 23.

These linear considerations arise from the screening results, which allowed some sort of linguistic homogeneity of the sample selected. However, it should be considered here that the use of a single instrument for the different studied grades may have influenced this result. The possibility of differences in amplitude and depth of vocabulary along the grades should also be noted. In a recent study, researchers reported that the vocabulary amplitude, that is, the size of the mental lexicon, would be more strongly related to the ability of reading comprehension than the richness of knowledge that the individual presents about the word3. The study about the effect of grade advancement on comprehension probably presented some results influenced by the fact that they used different texts for each grade. Furthermore, it was possible to critically examine the influence of text selection on the assessment and make some considerations. On the answers to multiple choice questions with propositions explicit in the text - subjected to short-term memory students of 4 th, 5th and 6th grades obtained performance superior than of the one students from 3rd grade in both educational settings, evidencing that on subsequent grades there was an increase in memory capacity. This result is similar to that obtained in a Brazilian study9. On the answers to questions with implicit text aspects, the 4 th grades from both settings performed significantly better
TABLE 2. Mean and Median Percentage obtained on reading comprehension evaluation according to grade and school setting - Public or Private.

\begin{tabular}{|c|c|c|c|c|c|c|c|}
\hline & & & \multicolumn{4}{|c|}{ GRADE } & \multirow{2}{*}{$\begin{array}{l}\text { ANOVA } \\
(p)\end{array}$} \\
\hline & & & $3 \mathrm{rd}$ & 4th & 5 th & 6th & \\
\hline \multirow{6}{*}{$\mathrm{PuS}$} & Macropropositions & Mean & 0,76 & 0,72 & 0,63 & 0,88 & $0,004 *$ \\
\hline & & $\mathrm{SD}$ & 0,27 & 0,21 & 0,19 & 0,16 & \\
\hline & & & & & & & $\begin{array}{l}\text { Kruskal- } \\
\text { Wallis (p) }\end{array}$ \\
\hline & Explicit Questions & Median & 2,00 & 3,00 & 3,00 & 3,00 & $0,001 *$ \\
\hline & Implicit Questions & Median & 2,00 & 3,00 & 1,00 & 1,50 & $<0,001 *$ \\
\hline & $\begin{array}{c}\text { Comprehension } \\
\text { level }\end{array}$ & Median & 2,00 & 2,00 & 1,00 & 1,50 & $<0,001 *$ \\
\hline \multirow{7}{*}{$\operatorname{PrS}$} & & & & & & & ANOVA (p) \\
\hline & Macropropositions & Mean & 0,79 & 0,74 & 0,70 & 0,94 & $<0,001 *$ \\
\hline & & $\mathrm{SD}$ & 0,17 & 0,20 & 0,10 & 0,11 & \\
\hline & & & & & & & $\begin{array}{c}\text { Kruskal- } \\
\text { Wallis (p) } \\
\end{array}$ \\
\hline & Explicit Questions & Median & 2,00 & 3,00 & 3,00 & 3,00 & $0,003 *$ \\
\hline & Implicit Questions & Median & 2,00 & 3,00 & 2,00 & 2,50 & $<0,001 *$ \\
\hline & $\begin{array}{c}\text { Comprehension } \\
\text { level }\end{array}$ & Median & 2,00 & 2,00 & 1,00 & 2,00 & $<0,001 *$ \\
\hline
\end{tabular}

$\mathrm{SD}=$ Standard Deviation

than the other grades. However, if the texts would have been selected for each grade, this result may have been influenced by the easiness of the 4th grade text, once it was also used to assess anterior grades 9 .

When the percentage of retold macropropositions was studied, it was noted that the 6th grades of the two settings mentioned a greater number when compared to the other grades. The text selected for this grade was the shortest one which may have influenced the result 7 . This way, one could think that the amount of macropropositions reported after reading had less relation to the level of comprehension than to the memory capacity of the student 24 . In fact, even superficially comprehending, the reader might recall, summarize or respond to questions about the read content1.

Assessment of comprehension by the identification of levels could evidence, at the PuS setting, that the performance of children in 3rd and 4th grades was similar and better than the one in 5 th and 6th grades. Furthermore, the analysis of the PrS results showed a poorer performance of the 5 th grade in relation to others. These results may suggest a smaller number of resources of the 6th 
grade students of $\mathrm{PuS}$ in comparison to students from PrS, besides the influence of the selected text for 5 th grade on the performance of both settings. It should be noticed that not all participants achieved a complete text comprehension, once Level 2 of comprehension was not always achieved. Once more, the selected text may have influenced the result.

The ability to construct inferences is crucial on the differentiation of individuals on reading comprehension 25. Therefore, it would be important for these children to receive a later assessment or to be able to start a program that stimulates the ability to generate inferences.

Finally, it was verified that, even among the 160 students considered good readers and with expected performance in decoding, there were differences in the comprehension achieved, characterized mainly by the task of questions of implicit knowledge, linked to the generation of inferences. However, it should be highlighted that the responses resulted from multiple choice options which may have facilitated the process of cognitive inference, or maybe its non use, because of the fact that the answers were already presented 6,26.

These analyzes showed that some evidences

\section{References}

1. Sánchez EM. Compreensão e redação de textos: dificuldades e ajudas. Porto Alegre: Artmed; 2002.

2. Meneghetti C, Carreti B, De Beni R. Components of reading comprehension and scholastic achievement. Learning and Individual Differences. 2006;16:291-301.

3. Protopapas A, Sideridis GD, Mouzaki A, Panagiotis GS. Development of lexical mediation in the relation between reading comprehension and word reading skills in Greek. Scientific Studies of Reading. 2007;(11)3:165-97.

4. Tannenbaum KR, Torgesen JK, Wagner RK. Relationships between word knowledge and reading comprehension in third-grade children. Scientific Studies of Reading. 2006;10(4):381-98.

5. Cain K, Oakhill J. Profiles of children with specific reading comprehension difficulties. British Journaul of Educactional Psychology. 2006a;76:683-96.

6. Cain K, Oakhill J. Assessment matters: Issues in the measurement of reading comprehension. British Journaul of Educactional Psychology. 2006b;76:697-708.

7. Kintsch W. Comprehension: a paradigm for cognition.New York: Cambridge University Press; 1998.

8. Oakhill J, Hartt J, Samols D. Levels of comprehension monitoring and working memory in good and poor comprehenders. Read Writ. 2005;18:657-86. were more promising than others. Thus, the assessment of comprehension level seemed to be appropriate in a way that it determined more similarities than differences on performances among grades - which was expected given the prior selection of texts. Moreover, it should be considered that this assessment sought to identify the essential macrostructures, that is, the text essence, when achieved by the reader 1 .

More studies should be conducted to confirm the results reported here and to assess the clinical applicability of this reading comprehension and its disorders assessment.

\section{Conclusions}

Students of all grades, from both educational settings - Public and Private -, considered as good readers by their teachers, showed similar performance on retelling tasks and answers to explicit questions. Only at 5th and 6th grades, an improved performance of $\mathrm{PrS}$, compared to children from $\mathrm{PuS}$ in responses to questions of implicit knowledge was verified. All participants achieved some level of text reading comprehension.

9. Salles JF, Parente MAMP. Compreensão textual em alunos da segunda e terceira séries: uma abordagem cognitiva. Estudos de Psicologia. 2004;9(1):71-80.

10. Braz HA, Pellicciotti THF. Exame de linguagem Tipiti. São Paulo: MNJ LTDA; 1988.

11. Salles JF, Parente MAMP. Processos cognitivos na leitura de palavras em crianças: relações com compreensão e tempo de leitura. Psicologia: Reflexão e Crítica. 2002;(15)2: 321-331.

12. Kintsch W, van Dijk TA. Toward a model of text comprehension and production. Psychological Review. $1978 ; 85(5): 363-94$.

13. Kintsch, W. The role of knowledge in discourse comprehension: a construction-integration model. Psychological Review. 1988;95(2):163-82.

14. Scliar-Cabral L. Guia prático de alfabetização. São Paulo: Contexto; 2003.

15. Capellini SA, Cavalheiro LG. Avaliação do nível e da velocidade de leitura em escolares com e sem dificuldade na leitura. Temas sobre desenvolvimento. 2000;9(51):5-12.

16. Batista AS, Lemos CM, Rodrigues AN, Silva MA, Ávila CRB. Velocidade de leitura de textos e itens isolados: análise comparativa em escolares da RPU e particular de ensino. VIII Congresso Brasileiro de Neuropsicologia, São Paulo; 2005. 
17. Ramos CS. Avaliação da leitura em escolares com indicação de dificuldades de leitura e escrita [dissertação]. São Paulo (SP): Unifesp; 2005.

18. Oakhill JV, Petrides A. Sex differences in the effects of interest on boys' and girls' reading comprehension. British Journal of Psychology. 2007;98:223-35.

19. Carvalho CAF, Batista AS, Paolucci J, Ávila CB, Chiari BM. Evaluation of reading comprehension with and without text consultation. In: Fourteenth Annual Meeting Society for the Scientific Study of Reading; 2007, Praga, República Tcheca.

20. Oakhill JV, Cain K, Bryant PE. The dissociation of word reading and text comprehension: Evidence from component skills. Language and Cognitive Processes 2003;18(4):443-68.

21. Cain K, Oakhill JV, Bryant PE. Phonological skills and comprehension failure: a test of the phonological processing deficit hypothesis. Read Writ. 2000;13:31-56.
22. Allbritton D. Strategic production of predictive inferences during comprehension. Discourse Processes. 2004;38(3):309-22.

23. Rapp DN, van den Broek P, McMaster K1, Kendeou P, Espin CA. Higher-order comprehension processes in struggling readers: a perspective for research and intervention. Scientifics Studies of Reading. 2007;11(4):289-312.

24. Carvalho CAF. Relação entre a função pragmática da linguagem e compreensão de texto [dissertação]. São Paulo (SP): Unifesp; 2008.

25. Oakhill JV. Inferential and memory skills in children's comprehension of stories. British Journal of Educational Psychology. 1984;54:31-39.

26. Keenan JM, Betjemann RS. Comprehending the gray oral reading test without reading it: why comprehension tests should not include passage-independent items. Scientific Studies of Reading. 2006;(10)4:363-80. ed hearing loss. New York: Thieme; 1996. p. 98-112. 